\title{
О СВЯЗИ СИЛЬНЫХ ГЕОДИНАМИЧЕСКИХ ВОЗДЕЙСТВИЙ С ПОВЫШЕНИЕМ СОДЕРЖАНИЯ РТУТИ В ВОДЕ ИСТОКА Р. АНГАРА (БАЙКАЛЬСКАЯ РИФТОВАЯ ЗОНА)
}

Ключевский А. В., Гребенщикова В. И., Кузьмин М. И., Демьянович В. М., Ключевская А. А.

\begin{abstract}
Аннотация
Результаты определения содержания ртути (Hg) в воде истока р. Ангара сопоставлены с сейсмическим процессом на различных масштабных уровнях литосферы Байкальской рифтовой зоны (БРЗ), с геодинамической активизацией Южно-Байкальской структуры-аттрактора рифтогенеза (САР) и с распределением во времени землетрясений с магнитудой $\mathrm{M} \geq 7$, произошедших на значительном удалении от пункта отбора воды. Коэффициенты корреляции, рассчитанные между рядами пар Нg и чисел землетрясений n, Hg и логарифма суммарной сейсмической энергии $\log \Sigma \mathrm{ES}$, чаще всего низки, что указывает на отсутствие статистически значимой связи между отдаленным сейсмическим процессом и динамикой выделения ртути. Однако в окрестностях истока р. Ангара коэффициенты корреляции высоки, что доказывает связь процесса выделения ртути с деформированием этой территории. Статистическая достоверность причинно-следственной связи “деформации - выделение ртути” подтверждается тем, что всем значимым максимумам $\mathrm{Hg}$ предшествуют сильные геодинамические воздействия. В период 19971998 г. основное воздействие оказала Южно-Байкальская САР, которая находилась в фазе максимальной геодинамической активности. Совместное влияние САР и Южно-Байкальского землетрясения 1999 года проявилось в серии максимальных значений содержания ртути в 19992000 годах. Последующее постепенное ослабление активности САР фиксируется в уменьшении среднегодового содержания ртути, а значимым максимумам Hg предшествуют удаленные землетрясения с магнитудой $\mathrm{M} \geq 7$ и близкие сильные землетрясения БР3. Прогнозные оценки тренда среднегодового содержания ртути указывают на возможность сильного повышения концентрации ртути в областях флюидной разрядки разломов при мощном геодинамическом воздействии САР или сильном землетрясении. В качестве механизма реализации предположено, что при сильном геодинамическом воздействии в исследуемой области литосферы происходит раскрытие зон разломов, которое приводит к декомпрессии со вскипанием и дегазацией ртути с быстрым подъемом на поверхность.
\end{abstract}

\section{Ключевые слова:}

Оз. Байкал, исток р. Ангара, содержание ртути в воде, геодинамические воздействия, сильные землетрясения, сейсмичность 
УДК 550.(343.3+348.098+348.436+394.4)

\title{
О СВЯЗИ СИЛЬНЫХ ГЕОДИНАМИЧЕСКИХ ВОЗДЕЙСТВИЙ С ПОВЫШЕНИЕМ СОДЕРЖАНИЯ РТУТИ В ВОДЕ ИСТОКА Р. АНГАРА (БАЙКАЛЬСКАЯ РИФТОВАЯ ЗОНА)
}

\author{
А.В. Ключевский ${ }^{1}$, В.И. Гребенщикова ${ }^{2}$, М.И. Кузьмин ${ }^{2}$, \\ В.М. Демьянович ${ }^{1}$, А.А. Ключевская ${ }^{1}$
}

${ }^{1}$ Институт земной коры СО РАН, 664033, Иркутск, Лермонтова, 128, Россия

${ }^{2}$ Институт геохимии СО РАН, 664033, Иркутск, ул. Фаворского, 1а, Россия

\section{ВВЕДЕНИЕ}

Суперпозиция напряжений глобального, регионального и локального масштабов приводит к деформированию некоторых регионов и зон литосферы Земли с диссипацией сейсмотектонической энергии в виде землетрясений различных энергетических классов. Тектонические землетрясения отражают расположение и мощность источников деформирования литосферы, масштабы и строение разломной структуры блочной иерархии геосреды, а также распределение напряжений и деформаций, которые концентрируются на границах блоков в зонах разломов, инициируют и генерируют землетрясения [Садовский и др., 1987]. В настоящее время землетрясения являются одним из основных источников информации о структуре и современной геодинамике литосферы сейсмоактивных регионов. Геодинамические явления и процессы изучаются при статистической обработке параметров большого числа землетрясений: анализируются пространственные координаты (долгота $\lambda$, широта $\varphi$ эпицентра и глубина $h$ гипоцентра), время реализации (время в очаге $t_{0}$ ), энергия (магнитуда $M$, сейсмическая энергия $E_{\mathrm{S}}$ и энергетический класс $K_{\mathrm{P}}$, сейсмический момент $M_{0}$ ) и прочие характеристики.

Результаты проведенных исследований указывают на обусловленность сейсмичности и сильных землетрясений глобальными, региональными и локальными геодинамическими явлениями различной природы и мощности, вызвавшими изменения напряженно-деформированного состояния (НДС) или реологических свойств горных пород [Соболев, 1993; International..., 2002; Соболев, Пономарев, 2003; Завьялов, 2006]. Как и в других сейсмоактивных регионах, иерархически структурированная неоднородная разломно-блочная литосфера Байкальской рифтовой зоны (БР3) генерирует большое число землетрясений различных энергетических классов [Golenetsky, 1990]. По данным о сейсмических источниках установлены особенности современной геодинамики литосферы БРЗ: пространственная неоднородность и временная неустойчивость НДС, которые обусловлены наличием структур-аттракторов рифтогенеза (САР) - областей с максимальной деформационно-прочностной анизотропией геолого-геофизической среды [Ключевский, 2011а]. САР оказывают сильное влияние на современную геодинамику и сейсмичность литосферы БРЗ и Монголо-Байкальского региона [Klyuchevskii, 2004; Ключевский и др., 2009; Klyuchevskii, 2010; Ключевский, Ключевская, 2009; Demberel, Klyuchevskii, 2017]. Как известно [Логачев, 2003], современная геодинамика и вулканизм Монголо-Байкальского региона формируются при участии флюидных глубинных термальных ловушек, возникновение и размещение которых определяется какими-то более общими причинами, чем чисто тектоническое деформирование. По данным С.В. Гольдина 
с коллегами [2006] остатки астеносферы, сохранившиеся в виде выступа при неполном закрытии Палеоазиатского и Монголо-Охотского океанов [Van der Voo et al., 1999], являются основным источником деформации и эволюции литосферы БРЗ. Установленные в этой работе области максимальной деформации хорошо соответствуют расположению САР в литосфере БРЗ. Главной геодинамической особенностью САР являются импульсные инверсии оси максимального напряжения сжатия из вертикального положения, характерного для рифтогенеза, в горизонтальное, что создает силу отталкивания (push) от массивной Сибирской платформы [Ключевский, 2007; 2018]. Эти сильные геодинамические воздействия начинаются в шовной зоне контакта мощной Сибирской платформы и Амурской плиты [Ключевский, 2001; Летников, Ключевский, 2014] и могут быть выявлены при мониторинговых исследованиях физико-химических процессов, связанных с деформированием разломно-блочной литосферы, с подготовкой и реализацией сильных землетрясений [Коваль и др., 2003].

В настоящей работе результаты мониторинговых исследований содержания ртути в воде истока р. Ангара из оз. Байкал поставлены в соответствие с активизацией ЮжноБайкальской САР, с сейсмическим процессом на различных масштабных уровнях литосферы и с распределением во времени землетрясений с магнитудой $M \geq 7$, произошедших на разном удалении от пункта отбора воды. Примененные подходы ориентированы на выяснение причины значимых повышений содержания ртути в воде и изучение передачи энергии в литосфере, воздействия сильных геодинамических возмущений на системы разломов, механизма и природы переноса летучего вещества на поверхность Земли при деформировании разломно-блочной геосреды.

\section{МАТЕРИАЛЫ И МЕТОДИКА ОБРАБОТКИ}

Байкальская рифтовая система впадин и обрамляющих их разломов протягивается из западной Монголии вдоль оз. Байкал к южной Якутии на расстояние более 2 тысяч км и занимает Саяно-Байкальское сводовое поднятие, являющееся самой возвышенной частью восточно-сибирских и северомонгольских нагорий [Логачев, 2003]. Эта территория выделяется повышенным уровнем сейсмичности и характеризуется преимущественно “рифтовым” НДС литосферы, при котором преобладают землетрясения - сбросы [Golenetsky, 1990]. Структурно-неоднородная ослабленная литосфера БРЗ делится внутренними границами раздела по вертикали (разломные зоны) и по горизонтали (инверсионные слои делителя), что способствует ее дренированию поверхностными водами и мантийными флюидами через области региональных и глубинных разломов [Летников и др., 1996] и сформированную систему внутренних границ раздела литосферы. При активизациях САР в рифтовой зоне происходит своего рода “встряхивание и переупаковка” блоков земной коры и литосферы, изменяется структура разломных зон и системы внутренних границ, что приводит к переменам в пропускной способности дренирования [Ключевский, 2012]. Средняя мощность земной коры БРЗ составляет около 45 км, но под Байкалом её толщина уменьшается до 36 км [Недра..., 1981], причем в слоисто-блочной структуре осадочных пород Южной котловины озера сейсмические границы комплексов отложений выделены до глубин 10-12 км [Суворов, Мишенькина, 2005]. Мощность литосферы контрастно изменяется в зоне перехода от толстой (200 км) литосферы Сибирской платформы к утоненной до толщины земной коры литосфере БРЗ. Центральная часть рифтовой зоны и особенно Южно-Байкальская впадина оз. Байкал 
выделяются резким уменьшением мощности литосферы и большим количеством разломов, проникающих на различные глубины [Мишенькина и др., 2000]. Утоненная литосфера здесь деформирована намного сильнее, чем на флангах и окраинах БР3, а максимальная раздробленность фундамента разломами установлена под ЮжноБайкальской впадиной [Ключевский, Демьянович, 2002], являющейся “историческим ядром” [Логачев, 2001] и древнейшей САР [Ключевский, 2011б] Байкальской рифтовой системы. Именно в этом районе с 1997 года Институт геохимии СО РАН проводит основные мониторинговые исследования химического состава воды в оз. Байкал.

$\mathrm{K}$ настоящему времени собрана аналитическая информация примерно по 500 пробам воды Байкальской водной экосистемы. В практическом плане особый интерес представляет исследование содержания ртути, что связано как с ее специфическими химическими свойствами, токсичностью и высокой биоактивностью, так и с возможностью поступления ртути из разломов Байкальского рифта [Коваль и др., 2003]. Поэтому кроме макро- и микрокомпонентного анализа воды всегда определялось содержание ртути в воде [Гребенщикова и др., 2018; Grebenshchikova et al., 2019]. Содержание ртути в поверхностной и глубинной воде Байкала, истока Ангары и некоторых притоков определено атомно-абсорбционным методом с непламенным определением паров восстановленной атомарной ртути на приборе РА-915+ с приставкой РП-91 при компьютерной регистрации. Контроль точности измерений прибора осуществлялся путем ежегодного тестирования и регулировки прибора предприятием изготовителем (ЛЮМЭКС, г. Санкт-Петербург). Химический анализ воды выполнен на оборудовании аккредитованного ЦКП “Изотопно-геохимических исследований” Института геохимии СО РАН (аналитики Андрулайтис Л.Д., Рязанцева О.С.). Корректность результатов подтверждена анализом стандартных образцов состава воды Байкала.

В работе использованы основные результаты определения и анализа содержания ртути в воде истока р. Ангара - единственного стока оз. Байкал. Исток р. Ангара замыкает естественные потоки вещества оз. Байкал и является одной из ключевых позиций в его геохимическом балансе [Коваль и др., 2003]. В этом месте с 1997 по 2006 г. отбор проб и анализ воды осуществлялся подекадно, а с 2006 по 2013 годы - ежемесячно. Анализ графиков вариаций во времени содержания ртути $\mathrm{Hg}$ показал, что самые значительные максимумы и повышенный разброс данных наблюдаются в 1997-2000 гг. (Рис.1а). В период 2001-2006 годы волатильность данных постепенно уменьшается и на графиках видны отдельные максимумы $\mathrm{Hg}$ в 2002, 2004 и 2006 годах. С 2007 года наблюдается низкий уровень содержания ртути в воде, разброс данных минимален и на общем квазистационарном фоне видны небольшие максимумы в 2007, 2009 и 2012 годах (Рис.1б). Для оценки значимости указанных максимумов определено среднее значение $\mathrm{Hg}$ и его стандартное отклонение за полный период времени 1997-2013 гг. и за квазистационарный период 2007-2013 гг. Среднее содержание ртути по общей выборке данных 1997-2013 гг. равно 0.0025 мкг/литр при стандартном отклонении $\sigma=0.0037$ мкг/литр. Эти оценки позволяют детерминировать линией “2 сигма” на рис.1а отдельные максимумы и группы максимумов $\mathrm{Hg}$ на уровне значимости не ниже 0.05 в период 19972006 годы. Среднее содержание ртути по выборке данных 2007-2013 гг. равно 0.0007 мкг/литр при стандартном отклонении $\sigma=0.0006$ мкг/литр, что позволяет детерминировать 
линией “2 сигма” на рис.1б в 2007, 2009 и 2012 годах максимумы $\mathrm{Hg}$ на уровне значимости не ниже 0.05 .

В табл.1 представлены коэффициенты корреляции $\rho$, определенные при сопоставлении данных содержания ртути в воде с используемыми в работе выборками землетрясений различных магнитуд $M$ и энергетических классов $K_{\mathrm{P}}$, зарегистрированных за 1997-2013 гг. на разном удалении $r$ от пункта отбора воды (Рис.2 - Рис.6). Расчеты $\rho$ выполнены между рядами пар $\mathrm{Hg}$ и чисел землетрясений $n$ и между рядами пар $\mathrm{Hg}$ и логарифма суммарной сейсмической энергии $\left(\log \Sigma E_{\mathrm{S}}\right)$, пересчитанной из магнитуд или энергетических классов толчков, произошедших в интервалы времени между отборами воды. Аналогично были определены коэффициенты корреляции между рядами пар среднегодовых значений $\mathrm{Hg}$ и $\mathrm{n}, \mathrm{Hg}$ и $\log \Sigma E_{\mathrm{s}}$. Полученные коэффициенты корреляции низки и отрицательны для выборок отдаленных катастрофических $(M \geq 7)$ и сильных $\left(K_{\mathrm{P}} \geq 13\right)$ землетрясений БР3, что указывает на отсутствие статистически значимой связи между исследуемыми процессами. Положительные $\rho$ получены для выборок землетрясений с $K_{\mathrm{P}} \geq 9$ и $K_{\mathrm{P}} \geq 6$, произошедших в окрестностях истока р. Ангара на небольшой территории размером $1^{\circ} \times 1.8^{\circ}$ ( $K_{\mathrm{P}} \geq 9$, Рис.5) и $0.3^{\circ} \times 0.4^{\circ}$ (K $\geq 6$, Рис.6). Коэффициент корреляции пары среднегодовых данных $\mathrm{Hg}-\log \Sigma E_{\mathrm{S}}$ в площадке $0.3^{\circ} \times 0.4^{\circ}$ максимальный (см. Табл.1, $K_{\mathrm{P}} \geq 6, \rho \sim 0.75$ ), что указывает на связь динамики выделения ртути с сейсмотектоническим деформированием этой небольшой территории. Поскольку коэффициент корреляции пары $H g-n$ равен $\rho \approx 0.34$, то высокая корреляция рядов $\mathrm{Hg}-$ $\log \Sigma E_{\mathrm{S}}$ обусловлена наиболее сильными толчками.

Максимальный уровень и повышенная дисперсия содержания ртути в воде истока р. Ангара в 1997-2000 гг. корреспондируют во времени с активизацией Южно-Байкальской CAР в конце 1990-х годов [Klyuchevskii, 2014] и произошедшим на расстоянии около 26 км от пункта отбора воды сильным Южно-Байкальским землетрясением (25.02.1999; энергетический класс $K_{\mathrm{P}}=14.6$; моментная магнитуда $M_{\mathrm{W}}=6.0 ; \quad \varphi=51.64^{\circ} \quad$ с.ш., $\lambda=104.82^{\circ}$ в.д). Сочетание этих факторов и результаты табл.1 послужили основной предпосылкой для сопоставления времени активизации САР и реализации сильных и катастрофических землетрясений, как источников деформирования литосферы в окрестностях пункта отбора воды, со значимыми максимумами $\mathrm{Hg}$ в воде истока р. Ангара. Согласно данным GPS, в 1997 году пос. Листвянка, расположенный на западном берегу оз. Байкал около пункта отбора воды (см. Рис.5), был приподнят на 1-2 см относительно города Иркутска, расположенного на Сибирской платформе [Гольдин, 2004]. В работе [Klyuchevskii, 2014] этот подъем связывается с деформированием литосферы при объемном расширении Южно-Байкальской САР. Также известно [Летников и др., 1996; Ключевский, 2001; Летников, Ключевский, 2014], что сильные геодинамические воздействия на метастабильную разломно-блочную литосферу Байкальского рифта могут приводить к кратковременному раскрытию локальных участков шовной зоны глубинных разломов между Сибирской платформой и Амурской плитой и вызывать изменения флюидного режима. Шовные межплитные границы имеют каналы повышенной флюидопроводности, которые способны дренировать “аномальную” низкоскоростную мантию, имеющую флюидную природу [Артюшков и др., 1990]. Флюидизация верхних частей мантии способствует их плавлению с приращением объема, чему содействует также снижение всестороннего давления при раскрытии локальных участков зоны краевого шва. Это, в свою очередь, приводит к активизациям САР, 
инверсиям осей напряжений в литосфере БРЗ, реализации сильных землетрясений и возможному вскипанию и дегазации ртути с быстрым подъемом на поверхность по зонам раскрытых разломов.

\section{РЕЗУЛЬТАТЫ ИССЛЕДОВАНИЙ}

При проверке связи формирования повышенного содержания $\mathrm{Hg}$ с динамическим воздействием от сильных землетрясений нами были приняты во внимание сейсмические события различных магнитуд, произошедшие с 1997 по 2013 гг. на разном удалении $r$ от истока р. Ангара. Можно полагать, что при прочих равных условиях при одинаковом расстоянии $r$ геодинамическое воздействие от землетрясения большой магнитуды будет сильнее, чем от толчка малой магнитуды, а при равной магнитуде воздействие от близкого землетрясения будет сильнее, чем от удаленного. Поэтому в анализе были рассмотрены:

\section{А. Катастрофические землетрясения мира с магнитудой $M \geq 8.0$ (Рис.2).}

На рис.2а представлена карта эпицентров землетрясений мира с магнитудой $M \geq 8.0$. Видно, что землетрясения происходили преимущественно на значительном удалении от о3. Байкал. В текущем анализе были использованы три самые близкие внутриконтинентальные коровые землетрясения с $M=8.0$, произошедшие на территории Китая [http://www.isc.ac.uk/iscbulletin/search/catalogue/]:

1. 2001-11-14, $M=8.0, \quad \varphi=35.93^{\circ} \quad$ с.ш., $\quad \lambda=90.59^{\circ} \quad$ в.д., $r \approx 2150$ км к юго-западу;

2. 2008-03-20, $M=8.0, \quad \varphi=35.55^{\circ} \quad$ с.ш., $\quad \lambda=81.51^{\circ} \quad$ в.д., $r \approx 2650$ км к юго-западу;

3. 2008-05-12, $M=8.0, \quad \varphi=31.06^{\circ} \quad$ с.ш., $\quad \lambda=103.37^{\circ} \quad$ в.Д., $r \approx 2300$ км к югу.

На рис.2б представлено распределение моментов времени землетрясений с $M \geq 8$ (верхний ряд треугольных маркеров), совмещенное с графиком вариаций $\mathrm{Hg}$. В выборке катастрофических землетрясений мира представлено 68 событий с $M \geq 8.0$ и среднее число толчков в год равно 4. Такая частота событий позволяет почти всегда найти на рис.2а максимумы $\mathrm{Hg}$, близкие к моменту какого-либо землетрясения в период 1997-2006 годы. Однако видно, что большая часть землетрясений, произошедших за 2007-2013 гг., не находят отклика в повышении содержания ртути. Для выбранных нами трех самых близких к оз. Байкал землетрясений с $M=8.0$ видно, что первое из них (2001-11-14) предшествует во времени значимому максимуму содержания ртути 25.02.2002 г., а два последующих (2008-03-20, 2008-05-12) - максимуму 17.07.2009 г.

\section{Б. Сильнейшие землетрясения с магнитудой $7.9 \geq M \geq 7.0$ в радиусе 3000 км от истока р. Ангара (Рис.3).}

На рис.3 представлена карта эпицентров сильнейших землетрясений с $7.9 \geq M \geq 7.0$, произошедших в радиусе 3000 км от истока р. Ангара с 1997 по 2013 годы. Видно, что землетрясения происходили преимущественно на Дальнем Востоке и в Китае на значительном удалении от истока. В текущем анализе были использованы самые близкие внутриконтинентальные коровые землетрясения, произошедшие на территории России [http://www.isc.ac.uk/iscbulletin/search/catalogue/]:

1. Чуйское землетрясение с $M=7.4\left(\varphi=50.01^{\circ} \quad\right.$ с.ш., $\lambda=87.78^{\circ} \quad$ в.д., $r \approx 1220$ км к западу) и два его мощных афтершока с $M=7.0$, произошедшие с 27.09.2003 по 01.12.2003;

2. Култукское землетрясение 2008-08-27, $M=7.0, \quad \varphi=51.66^{\circ} \quad$ с.ш., $\quad \lambda=104.14^{\circ} \quad$ в.Д., $r \approx 60$ км к юго-западу;

3. Тувинское землетрясение 2012-02-26, $M=7.0, \quad \varphi=51.80^{\circ} \quad$ с.ш., $\quad \lambda=95.98^{\circ} \quad$ в.Д., $r \approx 610$ км к западу. 
Распределение моментов времени землетрясений с $7.9 \geq M \geq 7.0$, совмещенное с графиком вариаций содержания ртути в истоке р. Ангара, представлено на рис.2б нижним рядом маркеров (квадраты). Для выбранных нами пяти землетрясений видно, что Чуйские землетрясения 2003 года предшествуют во времени значимому максимуму содержания ртути 05.06.2004 г., Култукское землетрясение можно соотнести с максимумом 17.07.2009 года, а Тувинское землетрясение приближено во времени к максимуму 20.09.2012 г.

\section{В. Сильные землетрясения Байкальского региона}

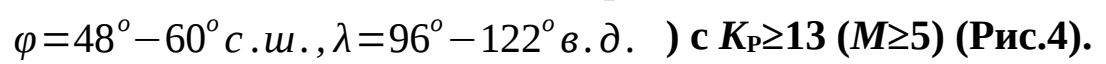

В выборке сильных землетрясений Байкальского региона с $K_{\mathrm{P}} \geq 13$ представлено 58 событий (рис.4a) [http://www.seis-bykl.ru], из них с $K_{\mathrm{P}} \geq 14-19$ толчков, с $K_{\mathrm{P}} \geq 15-4$ землетрясения. Почти все землетрясения произошли в рифтовой зоне, более половины - в пределах и обрамлении рифта оз. Байкал. Видно, что сильные землетрясения формируют пространственные группы в южной, центральной и северной части Байкальского рифта. На рис.4б представлено распределение моментов времени сильных землетрясений с $K_{\mathrm{p}} \geq 13$, совмещенное с графиком вариаций $\mathrm{Hg}$. Видно, что в начальной части графика нет землетрясений с $K_{\mathrm{P}} \geq 13$, однако имеются значимые максимумы $\mathrm{Hg}$. Первое сильное землетрясение произошло 25.02.1999 года (Южно-Байкальское, $K_{\mathrm{P}}=14.6$ ) и повлекло за собой серию афтершоков. Примечательно, что максимальное по полной выборке данных содержание ртути 0.028 мкг/литр было зафиксировано 05.02.1999 г. за 20 дней до ЮжноБайкальского землетрясения, что позволило рассматривать этот максимум в качестве предвестника Южно-Байкальского землетрясения [Коваль и др., 2003]. Содержание ртути понизилось перед землетрясением и 15.02.1999 г. составляло 0.0030 мкг/литр. После Южно-Байкальского события 26.02.1999 содержание ртути снова значительно повысилось до 0.0160 мкг/литр. Произошедшее на севере Байкала Кичерское землетрясение (21.03.1999 г., $K_{\mathrm{P}}=14.5$ ) не находит значимого повышения в $\mathrm{Hg}$. Достаточно явно причинно-следственные связи сильных землетрясений БРЗ с максимумами $\mathrm{Hg}$ прослеживаются в первой половине графика до 2006 года при сейсмических событиях 16.09.2003, $K_{\mathrm{P}}=14.3 ; 10.11 .2005, K_{\mathrm{P}}=15.7 ; 11.12 .2005, K_{\mathrm{P}}=14.8$. Во второй половине графика с 2007 года связи сильных землетрясений региона с максимумами $\mathrm{Hg}$ прослеживаются менее отчетливо при сейсмических событиях 27.08.2008, $K_{\mathrm{P}}=15.9$ (Култукское землетрясение); 26.01.2009, $K_{\mathrm{P}}=14.2 ; 16.07 .2011, K_{\mathrm{P}}=14.5$. В целом можно констатировать, что значимым максимумам $\mathrm{Hg}$ предшествуют сильные землетрясения БРЗ. Несомненна связь Южно-Байкальского землетрясения с повышением содержания ртути в воде.

\section{Г. Представительные землетрясения с $K_{\mathrm{P}} \geq 9(M \geq 3)$ в окрестностях истока р. Ангара (Рис.5).}

На рис.5а показана карта эпицентров представительных землетрясений с $K_{\mathrm{p}} \geq 9$, зарегистрированных с 1997 по 2013 годы в окрестностях истока р. Ангара [http://www.seisbykl.ru]. С целью детализации исследований в работе проанализированы землетрясения, произошедшие в трех площадках уменьшающихся размеров. Размеры площадки большой выборки данных $1^{\circ} \times 1.8^{\circ}\left(\varphi=51.3-52.3^{\circ} \quad\right.$ с.ш., $\lambda=103.9-105.7^{\circ} \quad$ в.д., число толчков $N=341)$, средней выборки данных $-0.8^{\circ} \times 1.4^{\circ}\left(\varphi=51.4-52.2^{\circ} \quad\right.$ с.ш., $\lambda=104.1-105.5^{\circ}$ в.д., $N=278)$ и малой выборки данных - $0.6^{\circ} \times 1.0^{\circ}\left(\varphi=51.5-52.1^{\circ} \quad\right.$ с.ш., $\lambda=104.3-105.3^{\circ} \quad$ в.д., $N=252$ ). На карте видно, что землетрясения происходили преимущественно под осевой частью акватории оз. Байкал. Зона повышенной плотности толчков на западе карты сформирована афтершоками Култукского землетрясения 2008 г., а 
в центральной части карты - афтершоками Южно-Байкальского землетрясения 1999 года. Далее к северо-востоку наблюдается рассеянная слабая сейсмичность. Небольшое число слабых землетрясений произошло на восточном побережье оз. Байкал, на западном берегу толчки с $K_{\mathrm{P}} \geq 9$ не зафиксированы. Видно, что Южно-Байкальское землетрясение и его афтершоки произошли в зоне пересечения и сочленения нескольких небольших разломов, ориентированных вдоль и поперек озера. Плотность разломов здесь существенно выше, а их ориентировки значительно разнообразнее, чем на остальной территории.

На рис.5б представлено распределение моментов времени землетрясений с $K_{\mathrm{P}} \geq 9$, зарегистрированных в трех площадках в окрестностях истока р. Ангара, совмещенное с графиками вариаций $\mathrm{Hg}$. Видно, что в начальной части графика до Южно-Байкальского землетрясения произошло всего 6 слабых толчков: 3 - в малой площадке, 4 - в средней и 6 - в большой. Это указывает, что в течение почти двух лет здесь имело место сейсмическое затишье, часто предшествующее сильному землетрясению [Соболев,1993]. Произошедшее 25.02.1999 года Южно-Байкальское землетрясение повлекло за собой продолжительную серию афтершоков, распределение которых во времени хорошо соответствует максимумам содержания ртути. Сильный афтершок 31.05.2000 года с $K_{\mathrm{P}}=13.4$ предшествует серии из трех значимых максимумов $\mathrm{Hg}$, начавшейся 04.08.2000 года. Поставить однозначно в соответствие менее сильные землетрясения и вариации $\mathrm{Hg}$ затруднительно. Однако следует отметить хорошо выделяющуюся на рис. $5 б$ компактную группу событий без сильного толчка (рой землетрясений), произошедших на небольшой площади ( $\varphi=51.5-51.6^{\circ} \quad$ с.ш., $\quad \lambda=104.6-104.7^{\circ} \quad$ в.Д., $\left.N=48\right)$ с 28.04 .2007 по 12.01.2008 и соответствующих во времени значимому повышению содержания ртути 08.08.2007. Сильное Култукское землетрясение в августе 2008 г. сформировало серию афтершоков, максимальный из которых имел $K_{\mathrm{P}}=13.2$. Это сильнейшее землетрясение Прибайкалья последнего времени и его афтершоки произошли в период минимального содержания ртути в воде, который продолжался до 17.07.2009, когда произошло значимое повышение содержания ртути. Последующие слабые землетрясения не имеют явной связи с изменениями $\mathrm{Hg}$.

\section{Д. Все зарегистрированные толчки с $K_{\mathrm{p}} \geq 6(M \geq 1.5)$ в окрестностях истока р. Ангара (Рис.6).}

На рис.6а представлена карта эпицентров 450 землетрясений с $K_{\mathrm{P}} \geq 6$, зарегистрированных с 1997 по 2013 годы в окрестностях истока р. Ангара на небольшой территории размером $0.3^{\circ} \times 0.4^{\circ}\left(\varphi=51.7-52.0^{\circ} \quad\right.$ с.ш., $\lambda=104.6-105.0^{\circ} \quad$ в.д.). На карте видно, что толчки происходили преимущественно к югу от истока р. Ангара. Зона повышенной плотности сформирована афтершоками Южно-Байкальского землетрясения. Около 30 слабых толчков с $K_{\mathrm{P}} \leq 8$ рассеяно на западном берегу оз. Байкал без какой-либо локализации и прибрежная зона крупного Обручевского разлома не находит явного отражения в сейсмичности. Несколько слабых толчков зарегистрировано около пунктов отбора воды в истоке р. Ангара.

На рис.6б представлено распределение моментов времени землетрясений с $K_{\mathrm{p}} \geq 6$, зарегистрированных в окрестностях истока р. Ангара, совмещенное с графиками вариаций $\mathrm{Hg}$. Видно, что в начальной части графика за два с лишним года до Южно-Байкальского землетрясения (1997- февраль 1999 гг.) произошло 8 слабых толчков, т.е. сейсмическое затишье фиксируется даже в очень слабых землетрясениях. Максимальный афтершок 31.05.2000 года с $K_{\mathrm{P}}=13.4$ формирует свою афтершоковую серию толчков и предшествует 
трем значимым максимумам $\mathrm{Hg}$ (04.08-19.09.2000 гг.). Последующие слабые землетрясения этой территории не находят явного отражения в значимых изменениях $\mathrm{Hg}$.

Чтобы выявить основной тренд изменения содержания ртути в истоке р. Ангара, имеющиеся фактические материалы за 1997-2019 гг. были сгруппированы в годовые массивы данных и определено среднее за год содержание ртути и стандартное отклонение. График изменений среднего по годам содержания ртути имеет понижающийся во времени тренд с вариациями не выше одного стандартного отклонения (Рис.7). Величина стандартного отклонения годовых данных изменяется от 0.0059 мкг/л до 0.00014 мкг/л, что указывает на кардинальное различие динамики процесса в начале (сильные флуктуации, процесс неустойчив) и в конце мониторинга (слабые флуктуации, процесс квазистационарен). Осредненные годовые данные хорошо аппроксимируются степенной зависимостью и при показателе степени -0.82 имеют высокий коэффициент корреляции $\rho \approx 0.84$. Отметим, что аналогичной зависимостью описывается релаксация геосреды после мощного динамического воздействия (главного землетрясения) в процессе афтершоковой серии [Mogi, 1963; Пшенников, 1965]. При экстраполяции графика в сторону уменьшения временного периода происходит рост уровня содержания ртути: на временном интервале месяц и полмесяца прогнозные значения содержания ртути составляют около 0.36 мкг/л и 0.64 мкг/л, что превышает предельно допустимую концентрацию водоемов рыбохозяйственного использования (0.01 мкг/л) и питьевой воды (0.5 мкг/л). Полученные прогнозные оценки отличаются от реальных замеров 1997-2019 гг., в которых содержание ртути не превышает 0.028 мкг/л. Однако эти оценки указывают на то, что при мощном геодинамическом воздействии САР или сильном близком землетрясении концентрация ртути может кратковременно значительно повышаться в локальной области флюидной разрядки разлома. Со временем локально высокое содержание ртути рассеивается по водному объему до повышенных, а затем и фоновых значений. При следующем мощном геодинамическом воздействии подобная динамика изменений содержания ртути в воде может реализоваться в другом месте, расположение которого зависит от распределения в литосфере градиента мощности возмущения и особенностей разломной структуры земной коры. При прочих равных условиях максимальные проявления роста содержаний ртути будут происходить в зонах повышенной трещиноватости литосферы.

Возможность такого сценария косвенно подтверждается графиками временных изменений концентрации ртути в воде истока р. Ангара, ручья пади Крестовая и колодца в пос. Листвянка (прежнее название пос. Лиственничное) за 1997-2001 гг., взятых из работы [Коваль и др., 2003] (Рис.8). Графики содержания ртути в этих трех пунктах отбора воды фактически повторяют друг друга и 05.02.1999 года имеют максимальные значения 0.028 (исток р. Ангара), около 0.04 (ручей) и около 0.023 мкг/л (колодец). Максимальная концентрация ртути на этой небольшой территории (см. Рис.6) различается почти в два раза. Совпадающая форма графиков на рис.8 указывает, что процесс не случайный: по содержанию ртути сильное геодинамическое воздействие проявляется одинаковым образом в разнесенных до 4 км пунктах отбора воды и, очевидно, является результатом деятельность одного общего источника большой мощности - Южно-Байкальской САР. Поскольку в вариациях $\mathrm{Hg}$ отражается эффект сильного геодинамического воздействия, максимум содержания ртути, зафиксированный 05.02.1999 года (до Южно-Байкальского землетрясения), является откликом на возбуждение САР. Этот максимум можно рассматривать как предвестник Южно-Байкальского землетрясения [Коваль и др., 2003], 
которое было вызвано (как пара с Кичерским землетрясением 21.03.1999 г., $K_{\mathrm{P}}=14.5$ ) геодинамической активизацией САР [Klyuchevskii, Khlebopros, 2013].

Чтобы проследить связь вариаций содержания ртути с флюидами, на рис.9 представлен график скорости потока 669 представительных землетрясений с $K_{\mathrm{P}} \geq 8$, зарегистрированных с 1997 по 2013 годы в малой площадке $0.6^{\circ} \times 1.0^{\circ}$ (см. Рис.5). На графике видно резкое нарастание чисел землетрясений $n$ на 756 сутки, вызванное афтершоками Южно-Байкальского землетрясения 1999 г. Следующий небольшой “скачок” $n$ обусловлен афтершоками достаточно сильного землетрясения-афтершока 31.05.2000 года. По окончании афтершоковой серии скорость потока толчков $n$ стабилизировалась, и так продолжалось до 3775 суток (28.04.2007 года), когда началось плавное быстрое нарастание чисел землетрясений. Анализ показал, что это нарастание связано с ускоренной реализацией 48 роевых толчков: такая форма нарастания $n$ типична для выделения роевых последовательностей в БР3 [Ключевская и др., 2015]. Также типичным является отсутствие в рое сильных землетрясений и реализация толчка максимального класса с $K_{\mathrm{p}}=10.1$ не в начале, а в средней части группы [Солоненко, Солоненко, 1987]. Этот рой землетрясений соответствует во времени повышению содержания ртути 08.08.2007 года и указывает на миграции флюида в это время: согласно К. Моги [Mogi, 1963] рои обычно реализуются в сильно раздробленной среде при направленном “концентрированном” приложении напряжения, как в случае движения магмы или потока флюида под высоким давлением. Рои землетрясений ассоциируются с зонами современного вулканизма и геотермальной активности при режиме тектонического растяжения. Д. Хилл [Hill, 1977] предложил модель реализации роя в виде миграций флюида через разветвленную сеть пересекающихся и взаимодействующих трещин сдвига и отрыва: такая сеть может функционировать как миграционные каналы для гидротермальных, углеводородных и магматических флюидов на различных масштабных уровнях литосферы. Фрикционная прочность разлома $\tau_{f r}$ может быть представлена в виде [Sibson, 2002]

$$
\tau_{f r}=\mu_{s}\left(\sigma_{n}-P_{f}\right) \text {, }
$$

где $\mu_{s}$ - статический коэффициент трения пород, $\sigma_{n}-$ нормальное напряжение на разломе, $P_{f}$ - давление флюида. Повышенное давление флюида создает физическое ослабление на разломе, приводит к падению эффективного нормального напряжения и может спровоцировать рой землетрясений. Ранее [Ключевский, 2005] реализация самой продолжительной в БРЗ Ангараканской роевой последовательности, начавшейся в 1979 году, связывалась с проходкой Северо-Муйского тоннеля трассы БАМ и нарушением режима подземных вод, которые выводились из тела Северо-Муйской межвпадинной горной перемычки через тоннель. Учитывая высокую плотность гидротермальных растворов, можно с большой степенью вероятности говорить о реальных условиях существования в литосфере Прибайкалья, особенно в ее верхней части, открытых разрывов, по которым происходит постоянное движение растворов [Шерман, 2017].

\section{ОБСУЖДЕНИЕ}

Поскольку изучение и прогноз сильных землетрясений является чрезвычайно важной научно-практической задачей, то мониторинг сейсмичности и геодинамических воздействий, а также исследование миграции деформационной активности, приводящей к сильным землетрясениям и возникающей после них, всегда были и будут актуальными. 
Подобные исследования ориентированы на решение фундаментальных задач формирования очага землетрясения и поиск механизмов генерации, переноса и распределения энергии в литосфере и в целом представляют комплексную научную проблему развития деформационного процесса, завершающегося сильным землетрясением или разрушением материала. Ее решение возможно при понимании эволюции НДС горных пород и материалов [Jackson et al.,. 1995; Макаров, Перышкин, 2016], охватывающей спектр ключевых процессов деформации и разрушения, в том числе процессы генерации деформационных возмущений, способных переносить энергию в твердом теле. Большую роль в этом познании играют мониторинговые исследования различных физико-химических процессов, связанных с сейсмотектоническим процессом, с подготовкой и реализацией сильных землетрясений [International..., 2002].

Обобщение полученных результатов представлено на рис.10, на котором видно, что всем значимым максимумам $\mathrm{Hg}$ предшествуют сильные геодинамические воздействия. В период 1997-1998 г. основное воздействие оказывает Южно-Байкальская САР, которая находится в фазе максимальной геодинамической активности в это время - серия значимых максимумов $\mathrm{Hg}$ при отсутствии региональных и приближенных к региону сильных землетрясений может быть объяснена деятельностью САР. Совместное влияние САР и Южно-Байкальского землетрясения 1999 года проявляется в серии максимальных значений $\mathrm{Hg}$, проявившихся в 1999-2000 годах. Постепенное ослабление деформационной деятельности САР наблюдается в уменьшении уровня среднегодового содержания ртути в воде (см. Рис.7) и отдельные значимые максимумы 2002 и 2004 гг. формируются после удаленного катастрофического землетрясения 2001-11-14, $M=8.0$ и Чуйских толчков 2003 года. Менее значительные максимумы в феврале-мае 2006 года имеют место после сильных землетрясений БРЗ (ноябрь-декабрь 2005 г.) на фоне дальнейшего ослабления активности САР. В последующие годы влияние САР минимально, содержание ртути в воде стабилизируется на уровне фона с редкими отдельными максимумами, которым предшествуют катастрофические землетрясений 2008 года с $M=8.0$, а также сильнейшее Култукское землетрясение и толчок 21.06.2009, произошедшие в БР3. Последнее значимое повышение содержания ртути в 2012 г. соотносится с Тувинским землетрясением 2012 года и с толчком 16.07.2011 в БРЗ. Более детальная информация по источникам сильных геодинамических воздействий, сформировавших значимые максимумы содержания ртути в воде истока р. Ангара, приведена в табл.2. Согласно табл.2, между сильными землетрясениями и эпизодами значимого повышения $\mathrm{Hg}$ имеется временной лаг, продолжительность которого зависит от удаленности и магнитуды землетрясения [Быков, 2005]. Связь слабых близких толчков с вариациями содержаний ртути не выявлена (кроме роевой последовательности 2007 года).

Определить основной фактор повышения $\mathrm{Hg}$ при наличии нескольких источников сильного геодинамического воздействия в настоящее время не представляется возможным. Оценки скорости передачи деформационного воздействия показывают, что они изменяются от 0.1 до 26 км/сутки (Табл.2). Обобщение данных, указывающих на возможность распространения в земной коре волновых деформационных процессов с различными скоростями, выполнено В.Г. Быковым [2005]. Глобальные тектонические волны со скоростями 10-100 км/год фиксируются по направленной миграции эпицентров сильных землетрясений, сейсмоскоростным аномалиям, волновым колебаниям уровня подземных вод вдоль зоны разлома, миграции наклонов и деформаций поверхности, 
деформографическим измерениям и пр. О деформационных волнах в разломах со скоростями 1-10 км/сутки свидетельствует миграция сейсмической активности, фиксируемые радоновые, электрокинетические и гидрогеодинамические сигналы, возбуждение волн деформаций и напряжений при взрывном и вибрационном инициировании подвижки в зоне разлома. Сильные землетрясения нередко сопровождаются миграцией сейсмической активности на обширных территориях [Hill et al., 1995; Hong et al., 2018]. В этом случае землетрясения служат природными детекторами деформационных волновых процессов, а возникающее взаимодействие между разломами, наряду с течением горных масс и перераспределением порового давления в ближней зоне, на удалении может обеспечиваться деформационными волнами. Скорости в табл.2 в большей степени соответствуют диапазону деформационных волн в разломах. Такие же скорости деформационных возмущений получены при анализе параметров сейсмических источников в литосфере Монголо-Байкальского региона [Demberel, Klyuchevskii, 2017] и мигрирующей сейсмичности в БР3 [Какоурова, Ключевский, 2020].

Согласно работе [Коваль и др., 2003], выявленные значительные флуктуации ртути в воде могут быть связаны с сейсмотектоническими процессами в БРЗ и в частности с ее поступлением из сейсмоактивных разломов (“ртутное дыхание”). Авторы полагают (с.236), что “подобно другим летучим элементам, ртуть может интенсивно выделяться из напряженной зоны в период предразрушения, являясь предвестником будущего сейсмического события. После снятия напряжений этот процесс прекращается и содержание ртути в воде быстро снижается до фонового уровня”. По результатам настоящей работы эта формулировка требует уточнения. Мы полагаем, что раскрытие локальных областей разломов в результате сейсмотектонических процессов или сильного геодинамического воздействия приводит к декомпрессии со вскипанием-дегазацией ртути и быстрым подъемом на поверхность по зонам раскрытых разломов. Выявление такой связи требует детального исследования поведения легко подвижных геохимических форм (ртуть, радон, гелий, углеводороды и др.) в связи с сейсмотектонической активностью БРЗ и ее структурой, в том числе и в глубинной воде. Это особенно важно в настоящее время, когда, судя по данным мониторинга за 2017-2019 гг., в воде вновь начинают появляться отдельные максимумы повышенного содержания ртути - токсичного вещества, имеющего высокую биологическую активность.

\section{ЗАКЛЮЧЕНИЕ}

Результаты определения содержания ртути в воде истока р. Ангара сопоставлены с активизацией Южно-Байкальской САР, сейсмическим процессом на различных масштабных уровнях литосферы и с распределением во времени землетрясений с магнитудой $M \geq 7$, произошедших на разном удалении от пункта отбора воды. Коэффициенты корреляции, рассчитанные между рядами пар $\mathrm{Hg}$ и $n, \mathrm{Hg}$ и $\log \Sigma E_{\mathrm{s}}$, чаще всего низки, что указывает на отсутствие статистически значимой связи между динамикой отдаленной сейсмичности и выделением ртути. Однако в окрестностях истока р. Ангара коэффициенты корреляции положительны и повышены, что доказывает связь процесса выделения ртути с деформированием этой небольшой территории. Достоверность этой связи подтверждена статистически - всем значимым максимумам $\mathrm{Hg}$ предшествуют сильные геодинамические воздействия. Прогнозные оценки тренда содержания ртути указывают на возможность сильного повышения концентрации ртути в локальной области 
флюидной разрядки разлома при мощном геодинамическом воздействии САР или сильном землетрясении. В качестве механизма реализации предположено, что при сильном геодинамическом воздействии в исследуемой области литосферы происходит раскрытие зон разломов, которое приводит к декомпрессии со вскипанием и дегазацией ртути с быстрым подъемом на поверхность по зонам раскрытых разломов. Проведенные исследования показали, что состояние воды Байкальской водной экосистемы зависит от природных катаклизмов. В связи с этим необходимо продолжение постоянных геохимических и геодинамических исследований в мониторинговом режиме.

Работа выполнялась при поддержке гранта РФФИофи_м №17-29-05022, проектов НИР (0350-2016-0027, 0346-2019-0001) и частичной финансовой поддержке РФФИ (№1757-44006).

\section{ЛИТЕРАТУРА}

Артюшков Е.В., Летников Ф.А., Ружич В.В. О разработке нового механизма формирования Байкальской впадины // Геодинамика внутриконтинентальных горных областей. Новосибирск, Наука, 1990, с. 367-376.

Быков В.Г. Деформационные волны Земли: концепция, наблюдения и модели // Геология и геофизика, 2005, т. 46 (11), с. 1176-1190.

Гольдин С.В. Дилатансия, переупаковка и землетрясения // Физика Земли, 2004, № 10, с. 37-54.

Гольдин С.В., Суворов В.Д., Макаров П.В., Стефанов Ю.П. Структура и напряженнодеформированное состояние литосферы Байкальской рифтовой зоны в модели гравитационной неустойчивости // Геология и геофизика, 2006, т. 47 (10), с.1094-1105.

Гребенщикова В.И., Кузьмин М.И., Пройдакова О.А., Зарубина О.В. Многолетний геохимический мониторинг истока реки Ангары (сток Байкала) // ДАН, 2018, т. 480, № 4, с. $449-454$.

Завьялов А.Д. Среднесрочный прогноз землетрясений: основы, методика, реализация. М., Наука, 2006, 254 с.

Какоурова А.А., Ключевский А.В. Мигрирующая сейсмичность в литосфере Байкальской рифтовой зоны: пространственно-временное и энергетическое распределение цепочек землетрясений // Геология и геофизика, 2020, №4 (В печати).

Ключевская А.А., Демьянович В.М., Ключевский А.В., Зуев Ф.Л., Какоурова А.А. Группы землетрясений и группирующаяся сейсмичность в литосфере Байкальской рифтовой системы // Геолого-геофизическая среда и разнообразные проявления сейсмичности. Нерюнгри, Из-во Технического института (ф) СВФУ, 2015, с.111-119.

Ключевский А.В. Локализация начальных действий мантийного диапира в зоне Байкальского рифта // ДАН, 2001, т.381, №2, с.251-254.

Ключевский А.В. Кинематика и динамика толчков в Ангараканской и Амутской сериях землетрясений Байкальского региона // Физика Земли, 2005, №1, с.3-18.

Ключевский А.В. Напряжения и сейсмичность на современном этапе эволюции литосферы Байкальской рифтовой зоны // Физика Земли, 2007, №12, с.14-26.

Ключевский А.В. Структуры-аттракторы рифтогенеза в литосфере Байкальской рифтовой системы // ДАН, 2011а, т. 437, №2, с.249-253.

Ключевский А.В. Аттракторы рифтогенеза как атрибут кайнозойского этапа эволюции литосферы Байкальской рифтовой системы // ДАН, 2011б, т. 440, №6, с.811-814.

Ключевский А.В. Напряженно-деформированное состояние литосферы Байкальской рифтовой зоны: некоторые аналогии с установленными в физической мезомеханике закономерностями деформирования структурно-неоднородных сред // Физическая мезомеханика, 2012, т. 15, № 3, с. 23-34. 
Ключевский А.В. Особенности сейсмогеодинамики литосферы Монголии // Физическая мезомеханика, 2018, т. 21, №2, с.118-131.

Ключевский А.В., Демьянович В.М. Сейсмодеформированное состояние земной коры Байкальского региона // ДАН, 2002, т. 382, №6, с. 816-820.

Ключевский А.В., Ключевская А.А. Сейсмический процесс в литосфере Байкальской рифтовой зоны: эпизоды синхронизации // ДАН, 2009, т. 425, №2, с. 240-244.

Ключевский А.В., Демьянович В.М., Джурик В.И. Иерархия сильных землетрясений Байкальской рифтовой системы // Геология и геофизика, 2009, т.50 (3), с.279-288.

Коваль П.В., Удодов Ю.Н., Андрулайтис Л.Д., Саньков В.А., Гапов А.Е. Ртуть в воде истока р. Ангары: пятилетний тренд концентрации и возможные причины его вариаций // ДАН, 2003, т. 389, №2, с. 235-238.

Летников Ф.А., Ключевский А.В. Структуры-аттракторы рифтогенеза в литосфере Байкальской рифтовой системы: природа и механизм образования // ДАН, 2014, т. 458, №1, c.52-56.

Летников Ф.А., Дорогокупец П.И., Савельева В.Б., Вилор Н.В., Лашкевич В.В., Медведев В.Я., Иванова Л.И., Балышев С.О., Меньшагин Ю.В., Медведева Т.И., Гантимурова Т.П., Сизых Н.В., Данилов Б.С., Аникина Ю.В., Менакер И.Г., Петрова E.B. Флюидный режим и геоэнергетика континентальной литосферы // Литосфера Центральной Азии. Новосибирск, Наука, 1996, с. 30-42.

Логачев Н.А. Об историческом ядре Байкальской рифтовой зоны // ДАН, 2001, т. 376, №4, c. $510-513$.

Логачев Н.А. История и геодинамика Байкальского рифта // Геология и геофизика, 2003, т.44 (5), с. 91-106.

Макаров П.В., Перышкин А.Ю. Моделирование “медленных движений” - автоволн неупругой деформации в пластичных и хрупких материалах и средах // Физическая мезомеханика, 2016, т. 19, № 2, с. 32-46.

Мишенькина 3.Р., Мишенькин Б.П., Петрик Г.В., Шелудько И.Ф. Возможности изучения литосферы методом глубинного сейсмического зондирования на примере Байкальской рифтовой зоны // Сейсмология в Сибири на рубеже тысячелетий. Новосибирск, Издательство СО РАН, 2000, с. 166-170.

Недра Байкала (по сейсмическим данным). Новосибирск, Наука, 1981, 105 с.

Пшенников К. В. Механизм возникновения афтершоков и неупругие свойства земной коры. М., Наука, 1965, 87 с.

Садовский М.А., Болховитинов Л.Г., Писаренко В.Ф. Деформирование геофизической среды и сейсмический процесс. М., Наука, 1987, 101 с.

Соболев Г.А. Основы прогноза землетрясений. М., Наука, 1993, 313 с.

Соболев Г.А., Пономарев А.В. Физика землетрясений и предвестники. М., Наука, 2003, 270 с.

Солоненко Н.В., Солоненко А.В. Афтершоковые последовательности и рои землетрясений в Байкальской рифтовой зоне. Новосибирск, Наука, 1987, 93 с.

Суворов В.Д., Мишенькина 3.P. Структура осадочных отложений и фундамента под Южной котловиной озера Байкал по данным КМПВ // Геология и геофизика, 2005, т.46 (11), с. 1159-1167.

Шерман С.И. Избранные труды. Тектоника разломообразования и сопутствующих процессов в литосфере. Иркутск, Ин-т земной коры СО РАН, 2017, 1476 с.

Demberel S., Klyuchevskii A.V. Lithospheric Stress in Mongolia, from Earthquake Source Data // Geosci. Front., 2017, v. 8, p. 1323-1337.

Golenetsky S.I. Problems of seismicity of the Baikal rift zone // J. Geodyn., 1990, v. 11, p. 293307.

Grebenshchikova V.I., Kuzmin M.I., Doroskov A.A., Zarubina O.V. The use of geochemical monitoring to assess the environmental impact on the ecosystem of Lake Baikal (Russia) // IOP 
Conference Series: Earth and Environmental Science, 2019, V. 381, 012030. DOI: 10.1088/1755-1315/381/1/012030

Hill D.P. A model for earthquake swarms // J. Geophys. Res., 1977, v. 82, p. 1347-1352.

Hill D.P., Johnston M.J.S., Langbein J.O., Bilham R. Response of Long Valley caldera to the $\mathrm{Mw}=$ 7,3 Landers, California, Earthquake // J. Geophys. Res., 1995, v. 100, № B7, p. 1298513005.

Hong T.K., Lee J., Park S., Kim W. Time-advanced occurrence of moderate-size earthquakes in a stable intraplate region after a megathrust earthquake and their seismic properties //Scientific Reports, 2018, 8, 13331. DOI:10.1038/s41598-018-31600-5.

International handbook of earthquake and engineering seismology. Lee, W. H. K., Kanamori, H., Jennings, P. C. \& Kisslinger, C. (eds.) Academic Press, Amsterdam, Boston, New York,.., Tokyo, 2002, part A, 934 pp.

Jackson D.D., Aki K., Cornell C.A. et al. Seismic hazards in southern California: probable earthquakes, 1994 to 2024 // Bull. Seism. Soc. Amer., 1995, v. 85, № 2, p. 379-439.

Klyuchevskii A.V. Seismic moments of earthquakes in the Baikal rift zone as indicators of recent geodynamic processes // J. Geodyn., 2004, v. 37, № 2, p.155-168.

Klyuchevskii A.V. Nonlinear geodynamics of the Baikal Rift System: an evolution scenario with triple equilibrium bifurcation // J. Geodyn., 2010, v. 49, № 1, p.19-23.

Klyuchevskii A.V. Rifting Attractor Structures in the Baikal Rift System: Location and Effects // J. Asian Earth Sci., 2014, v. 88, p. 246-256.

Klyuchevskii A.V., Khlebopros R.G. Coupled large earthquakes in the Baikal rift system: Response to bifurcations in nonlinear resonance hysteresis // Geosci. Front., 2013, v 6, № 4, p. 709-716.

Mogi K. Some discussions on aftershocks, foreshocks and earthquake swarms - the fracture of a semiinfinite body caused by an inner stress origin and its relation to the earthquake phenomena // Bull. Earthquake Res. Institute, 1963, Tokyo University, v. 41, p. 615-658.

Sibson R.H. Geology of the crustal earthquake source. In: International handbook of earthquake and engineering seismology, 2002, part A, 455- 473 pp.

Van der Voo R., Spakman W., Bijwaard H. Mesozoic subducted slabs under Siberia // Nature, 1999, v. 397, p. 246-249, doi:10.1038/16686.

[http://www.crust.irk.ru/patents 27.html] Институт земной коры Сибирского отделения Российской академии наук. Свидетельство о государственной регистрации базы данных №2016621339 “База данных сейсмогенных источников юга Восточной Сибири”. Авторы: Гладков А.А., Лунина О.В.

[http://www.isc.ac.uk] Internatl. Seismol. Cent., Thatcham, United Kingdom, 2019 [http://www.seis-bykl.ru] Байкальский филиал Федерального исследовательского центра “Единая геофизическая служба Российской академии наук” 
Подписи к рисункам в статье А.В. Ключевского, В.И. Гребенщиковой, М.И. Кузьмина, В.М. Демьяновича, А.А. Ключевской “О связи сильных геодинамических воздействий с повышением содержания ртути в воде истока р. Ангара”

Рис.1. Графики изменения во времени содержания ртути в воде истока р. Ангара и статистические оценки вариаций.

а - за период наблюдений 1997-2013 годы, б - за период наблюдений 2007-2013 годы.

Рис.2. Пространственно-временное распределение катастрофических землетрясений мира с магнитудой $M \geq 8.0$ (а) в совмещении с графиком содержания ртути за 1997-2013 годы (б).

На рис.2а район исследований показан маленьким прямоугольником на фоне оз. Байкал. На карте выделен большой прямоугольник, внутри которого кружками показаны эпицентры трех самых близких к району исследований внутриконтинентальных коровых землетрясений с $M=8.0$. Цифры у эпицентров соответствуют номерам землетрясений в тексте. Цветовая гамма шкалы отражает глубину гипоцентров землетрясений. На рис.2б стрелками показаны землетрясения с $M \geq 7.0$, предшествующие значимым максимумами содержания ртути в воде. С целью упрощения представления землетрясения с $M \geq 8.0$ и $7.9 \geq M \geq 7.0$ (кроме Чуйского главного толчка с $M=7.4$ ) собраны на линии $M=8$ и $M=7$ соответственно.

Рис.3. Карта эпицентров сильнейших землетрясений с 7.9 $\geq M \geq 7.0$, произошедших в радиусе 3000 км от истока р. Ангара за 1997-2013 годы.

Район исследований показан прямоугольником на фоне оз. Байкал. На карте выделен большой прямоугольник, внутри которого кружками показаны эпицентры пяти самых близких к району исследований внутриконтинентальных коровых землетрясений с $7.9 \geq M \geq 7.0$. Цифры у эпицентров соответствуют номерам землетрясений в тексте. Цветовая гамма шкалы характеризует глубину гипоцентров землетрясений.

Рис.4. Пространственно-временное распределение сильных землетрясений Байкальского региона с энергетическим классом $K_{\mathrm{p}} \geq 13$ (а) в совмещении с графиком содержания ртути в истоке р. Ангары за 1997-2013 годы (б).

На рис.4а район исследований показан прямоугольником на фоне оз. Байкал. Стрелки, названия и даты указывают и относятся к землетрясениям, отмеченным крупными крестиками на рис.4б. Градация землетрясений по классам приведена в легенде. На рис.4б стрелками показаны сильные землетрясения (крупные крестики), предшествующие значимым максимумам содержания ртути в воде.

Рис.5. Пространственно-временное распределение представительных землетрясений с $K_{\mathrm{p}} \geq 9$ в окрестностях истока р. Ангара (а) в совмещении с графиком содержания ртути за 1997-2013 годы (б).

1 - пункт отбора воды в истоке р. Ангара, 2 - разломы [http://www.crust.irk.ru/patents 27.html], 3 - площадка с роем землетрясений, 4 расположение пос. Листвянка, 5 - эпицентры землетрясений с $K_{\mathrm{p}} \geq 9$.

Внешний контур, средний и малый прямоугольники на рис.5а показывают территории, в пределах которых произошли землетрясения большой, средней и малой 
выборки данных. Стрелки, названия и даты указывают и относятся к сильным землетрясениям, отмеченным крупными крестиками на рис.5б. На рис.5б стрелками показаны сильные землетрясения (крупные крестики), предшествующие значимым максимумам содержания ртути в воде. Толчки большой, средней и малой выборки данных показаны крестиком, кружком и маркером +.

Рис.6. Пространственно-временное распределение землетрясений с $K_{\mathrm{p}} \geq 6$ в окрестностях истока р. Ангара (а) в совмещении с графиком содержания ртути за 19972013 годы (б).

Пункты отбора воды: 1 - исток р. Ангара, 2 - ручей в пади Крестовая, 3 - колодец в пос. Листвянка, 4 - разломы [http://www.crust.irk.ru/patents 27.html], 5 - эпицентры землетрясений с $K_{\mathrm{p}} \geq 6$. Звездочкой показано положение сильнейшего афтершока ЮжноБайкальского землетрясения (31.05.2000, $\left.K_{\mathrm{P}}=13.4\right)$. На рис.6б стрелкой показана связь афтершока 31.05.2000 (крупный крестик) со значимыми максимумами содержания ртути в воде.

Рис.7. График и тренд среднегодового содержания ртути в воде истока р. Ангара.

Рис.8. Вариации содержания ртути в воде.

а - исток реки Ангара, б - ручей в пади Крестовая, в - колодец в пос. Листвянка (Из [Коваль и др., 2003]). Расположение пунктов отбора воды показано на рис.6.

Рис.9. Скорость потока землетрясений с $K_{\mathrm{P}} \geq 8$, зарегистрированных в площадке $\varphi=51.5-52.1^{\circ} \quad$ с.ш., $\quad \lambda=104.3-105.3^{\circ} \quad$ в.д. за 1997-2013 годы.

Рис.10. Источники сильных геодинамических воздействий, сформировавших значимые максимумы содержания ртути в воде истока р. Ангара. 
Табл.1. Корреляция содержания ртути в воде $H g$ с числом $n$ и логарифмом суммарной сейсмической энергии $\log \Sigma E_{\mathrm{S}}$ землетрясений

\begin{tabular}{|c|c|c|c|c|c|c|}
\hline \multirow{3}{*}{$\begin{array}{c}\text { Дискретизация } \\
\text { данных }\end{array}$} & \multirow{3}{*}{$\begin{array}{c}\text { Сопоставляемые } \\
\text { ряды данных }\end{array}$} & \multicolumn{5}{|c|}{ Выборки землетрясений по магнитудам и энергетическим классам } \\
\hline & & $M \geq 8.0$ & $7.9 \geq M \geq 7.0$ & $K_{\mathrm{P}} \geq 13$ & $K_{\mathrm{P}} \geq 9$ & $K_{\mathrm{P}} \geq 6$ \\
\hline & & \multicolumn{5}{|c|}{ Коэффициенты корреляции $\rho$} \\
\hline \multirow{2}{*}{$\begin{array}{c}\text { С шагом } \\
\text { отбора воды } \\
\end{array}$} & $H g-n$ & -0.26 & -0.25 & -0.06 & 0.37 & 0.47 \\
\hline & $H g-\log \Sigma E_{\mathrm{S}}$ & -0.27 & -0.24 & -0.17 & -0.14 & 0.20 \\
\hline \multirow[b]{2}{*}{ Среднегодовая } & $H g-n$ & -0.53 & -0.50 & 0.29 & 0.23 & 0.34 \\
\hline & $H g-\log \Sigma E_{\mathrm{S}}$ & -0.56 & -0.51 & -0.50 & 0.11 & 0.75 \\
\hline
\end{tabular}


Табл.2. Источники сильных геодинамических воздействий, сформировавших значимые максимумы $\mathrm{Hg}$ в воде истока р. Ангара

\begin{tabular}{|c|c|c|c|}
\hline № & Время и уровень значимого максимума & Источник геодинамического воздействия & Скорость, км/сутки \\
\hline 1 & 21.08.-02.09.1997 года, 0.0217 мкг/литр & Южно-Байкальская САР & \\
\hline 2 & 25.08.-16.10.1998 года, 0.0210 мкг/литр & Южно-Байкальская САР & \\
\hline \multirow[b]{2}{*}{3} & \multirow[b]{2}{*}{ 05.02.-26.02.1999 года, 0.0280 мкг/литр } & Южно-Байкальская САР & \\
\hline & & Южно-Байкальское, 25.02.1999; $K_{\mathrm{P}}=14.6$ & 26 \\
\hline \multirow[b]{2}{*}{4} & \multirow[b]{2}{*}{ 04.08.-19.09.2000 года, 0.0140 мкг/литр } & Южно-Байкальская САР & \\
\hline & & Афтершок, 31.05.2000 г., $K_{\mathrm{P}}=13.4$ & 0.1 \\
\hline \multirow[b]{2}{*}{5} & \multirow[b]{2}{*}{ 25.02.2002 года,, 0.0170 мкг/литр } & Южно-Байкальская САР & \\
\hline & & Землетрясение 14.11.2001 г., M=8.0 & 21 \\
\hline 6 & 25.09.2002 года, 0.0167 мкг/литр & Южно-Байкальская САР & \\
\hline \multirow[b]{3}{*}{7} & \multirow[b]{3}{*}{ 05.06.2004 года, 0.0220 мкг/литр } & Южно-Байкальская САР & \\
\hline & & Три Чуйские, 27.09.2003, $M=7.4,7.0,7.0$ & 5 \\
\hline & & Землетрясение БР3 16.09.2003, $K_{\mathrm{P}}=14.3$ & 2.5 \\
\hline \multirow[b]{2}{*}{8} & \multirow[b]{2}{*}{ 05.06.2006 года, 0.0090 мкг/литр } & Землетрясение БР3 10.11.2005, $K_{\mathrm{P}}=15.7$ & 5.5 \\
\hline & & Землетрясение БР3 11.12.2005, $K_{\mathrm{P}}=14.8$ & 7 \\
\hline 9 & 08.08.2007 года, 0.0020 мкг/литр & Рой толчков 28.04.2007-19.05.2008 & \\
\hline \multirow{4}{*}{$\begin{array}{l}1 \\
0\end{array}$} & \multirow[b]{4}{*}{ 17.07.2009 года, 0.0028 мкг/литр } & Землетрясение 20.03.2008 г., $M=8.0$ & 5.5 \\
\hline & & Землетрясение 12.05 .2008 г., $M=8.0$ & 5.3 \\
\hline & & Култукское, 27.08.2008, $K_{\mathrm{P}}=15.9$ & 0.2 \\
\hline & & Землетрясение БР3 26.01.2009, $K_{\mathrm{P}}=14.2$ & 7 \\
\hline \multirow[b]{2}{*}{11} & \multirow[b]{2}{*}{ 20.09.2012 года, 0.0035 мкг/литр } & Тувинское, $02.06 .2012, M=7.0$ & 5.5 \\
\hline & & Землетрясение БР3 16.07.2011, $K_{\mathrm{P}}=14.5$ & 0.6 \\
\hline
\end{tabular}




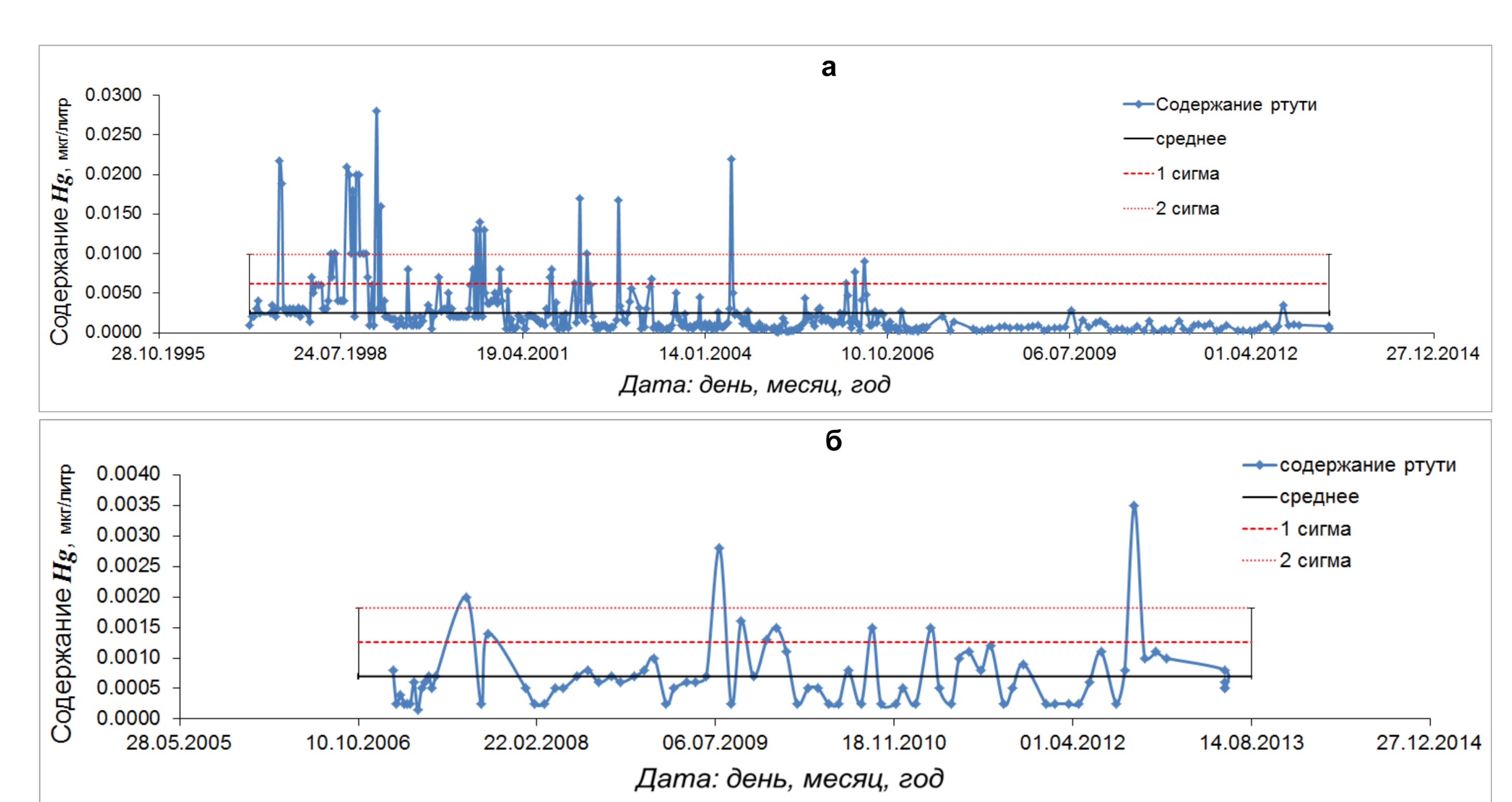




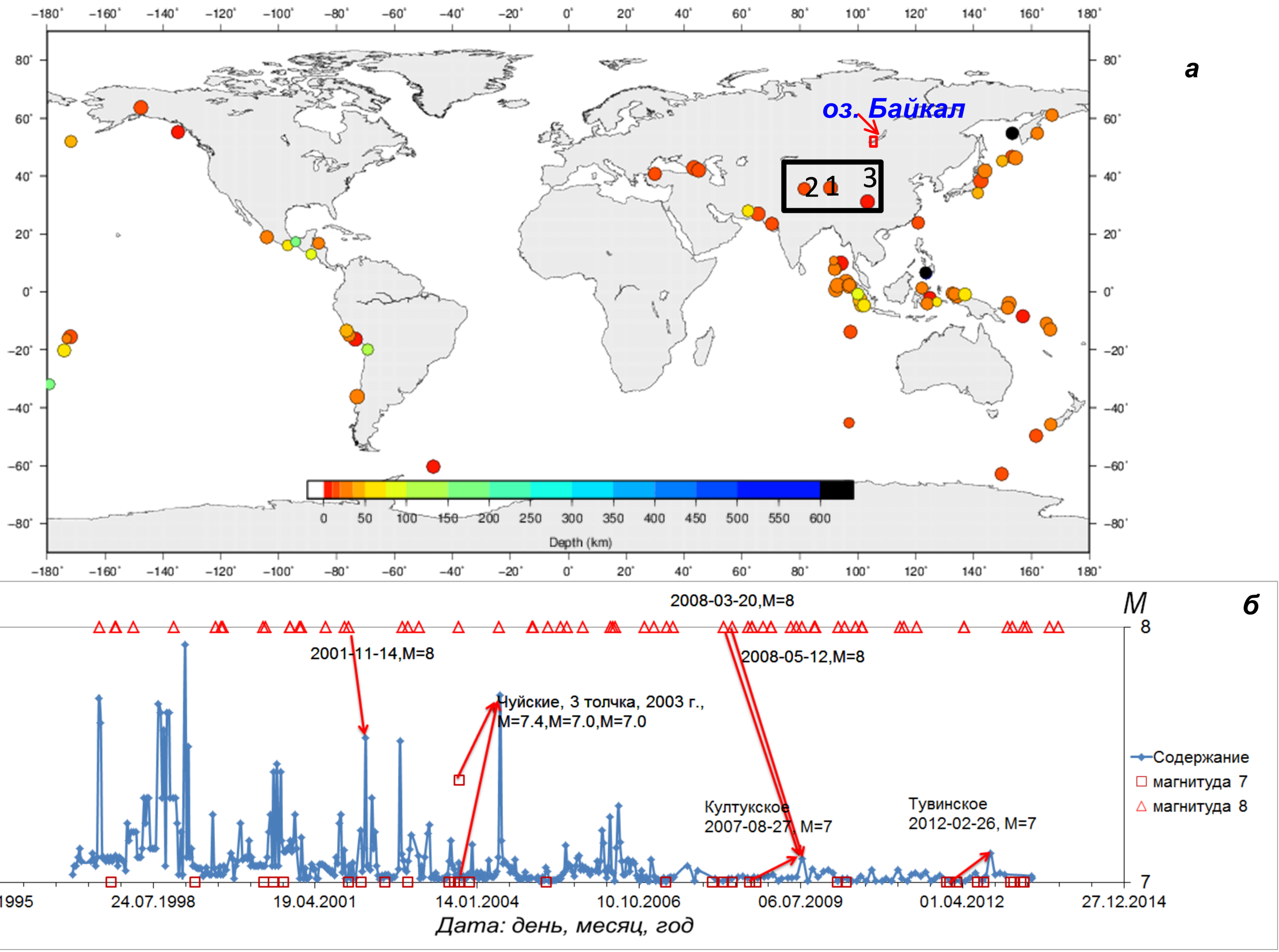




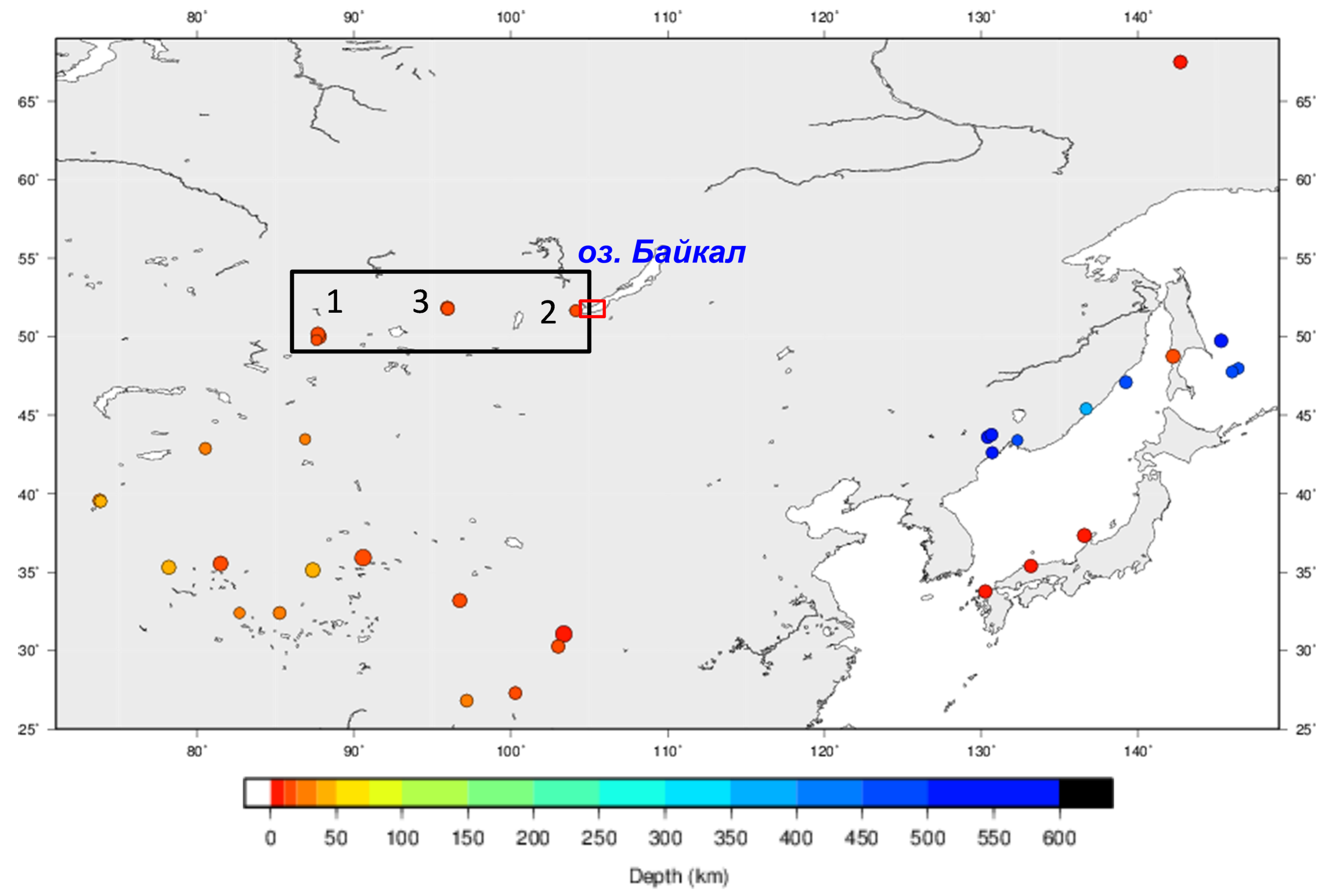



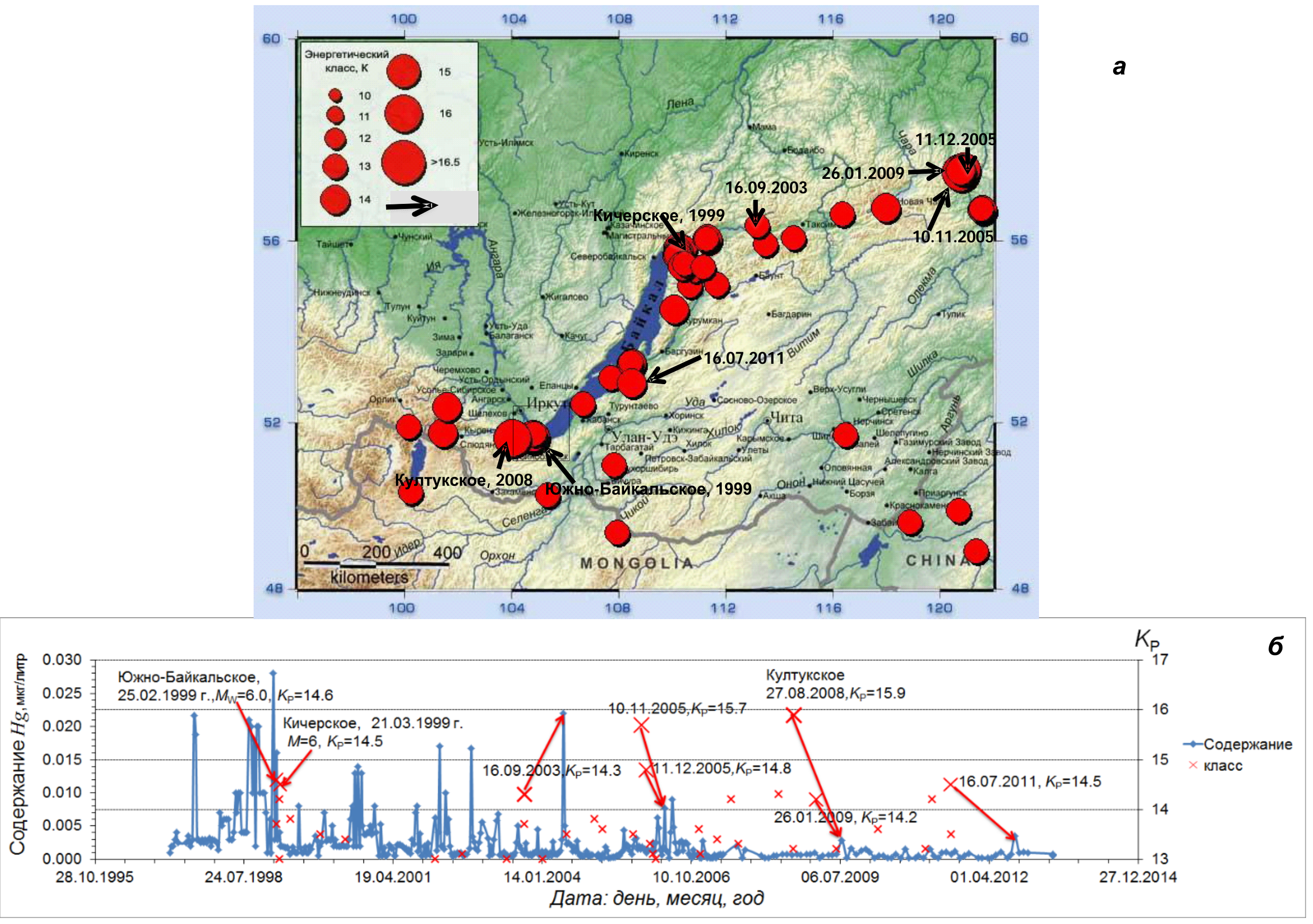


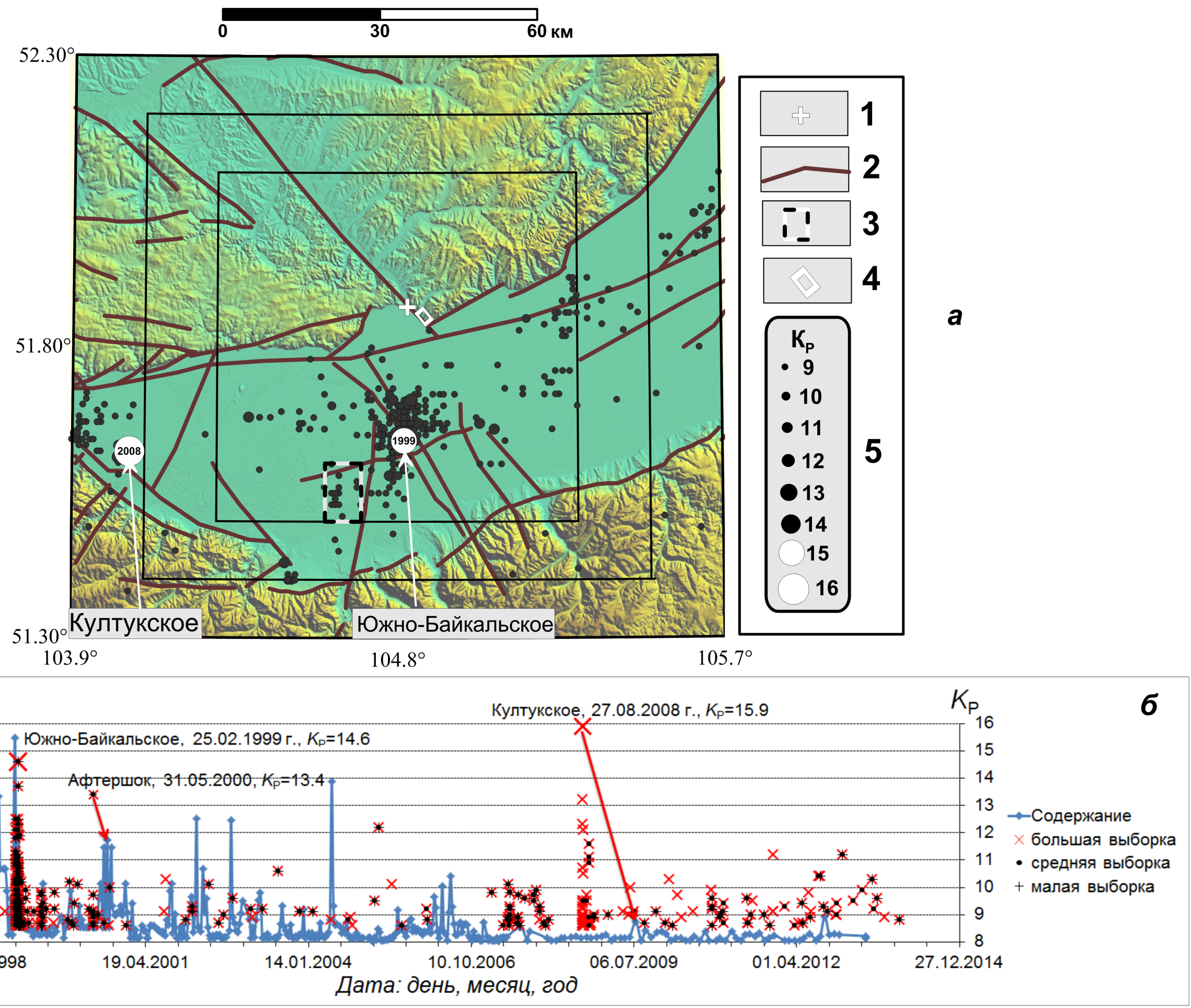




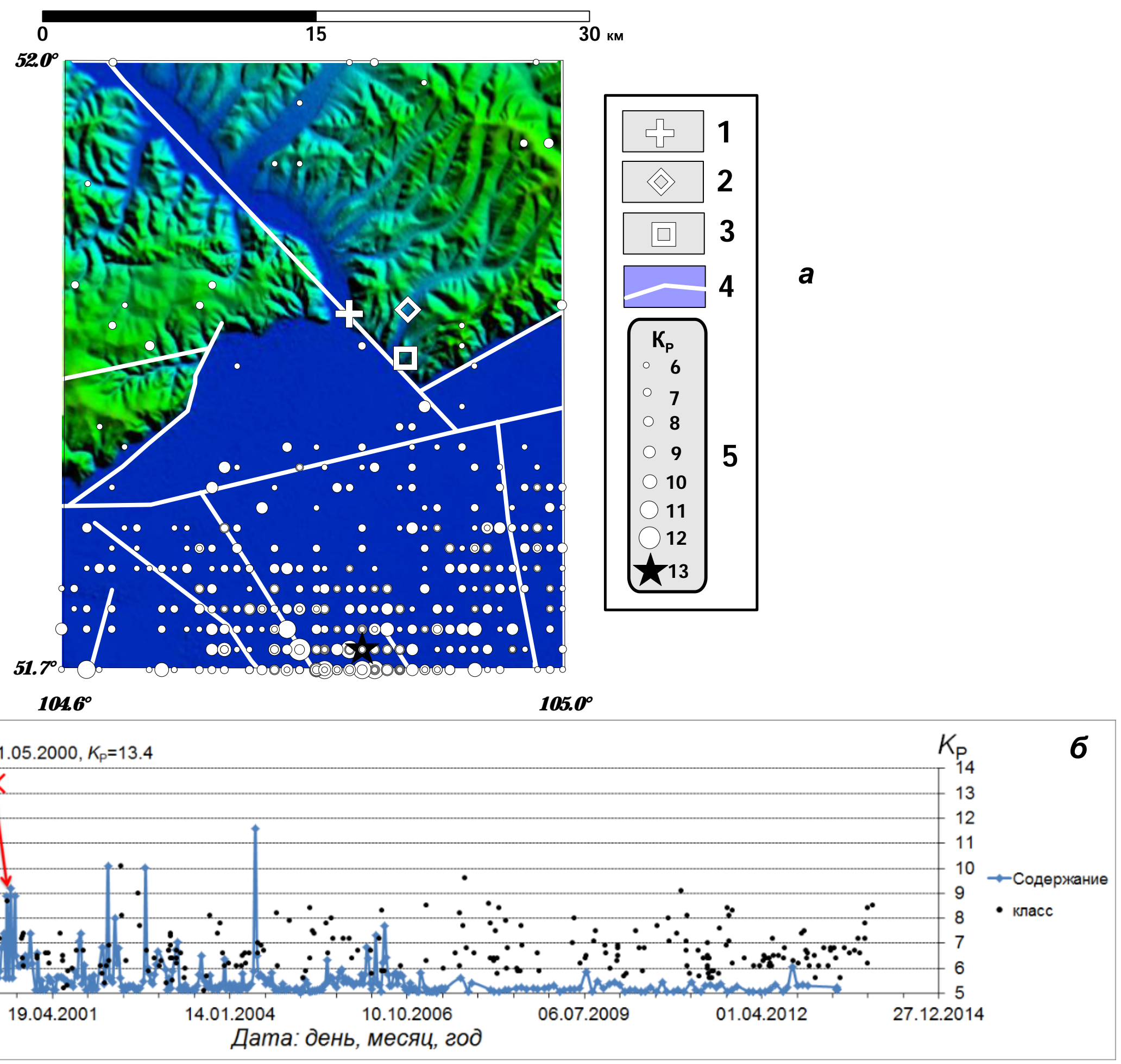




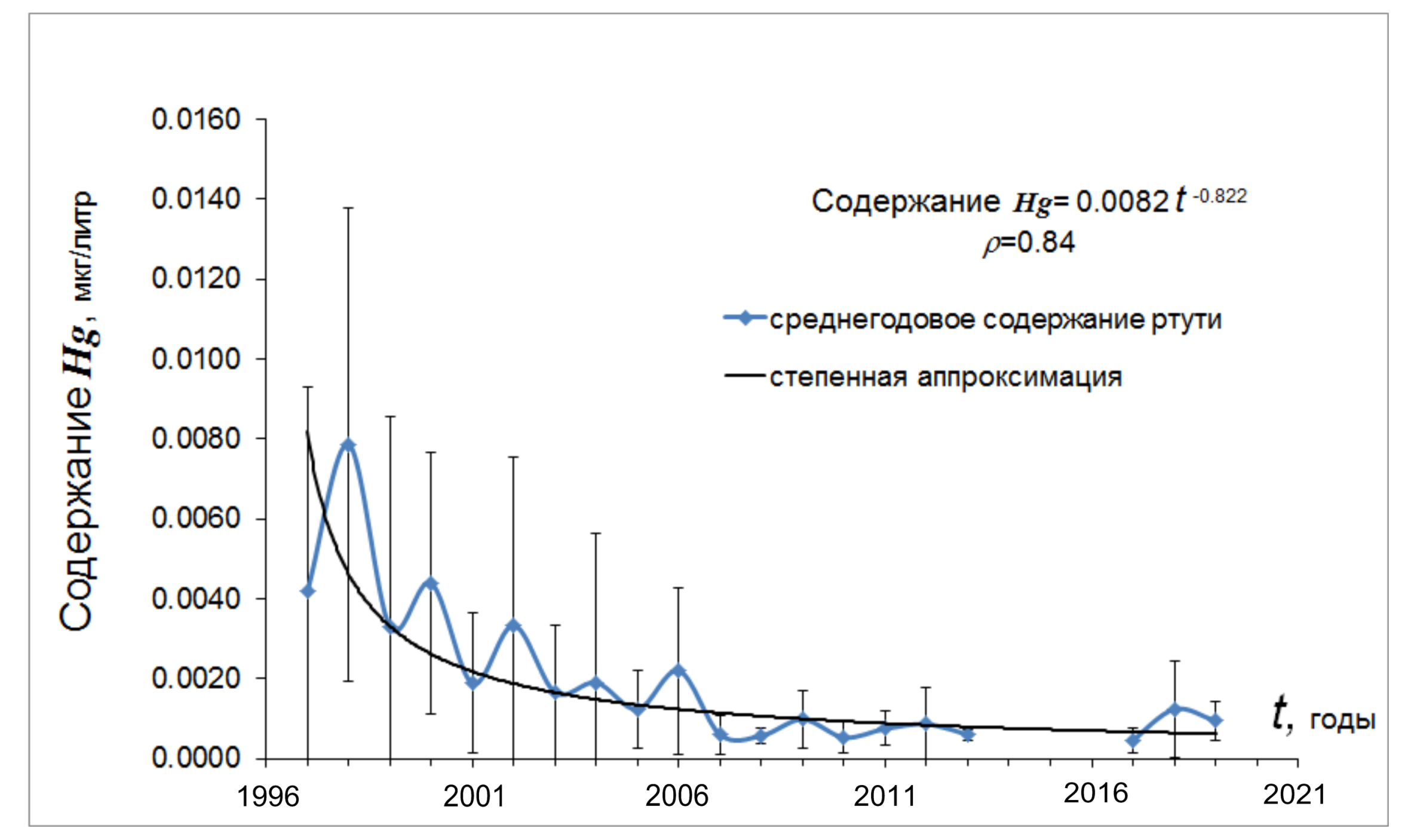


[Hg], мкг/л
0.03 -
$0.02-$
$0.01-$
0

(2)

0.04

0.03

0.02 0.01

0

0.04 0.03 0.02 0.0

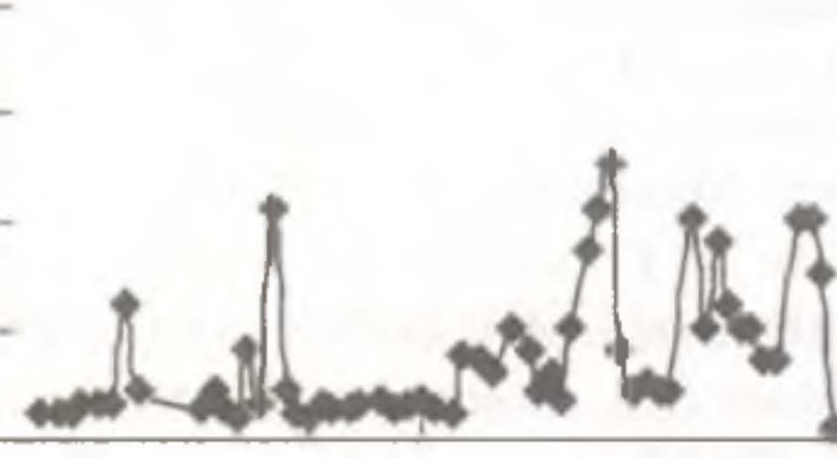

(6)

(B)

B)
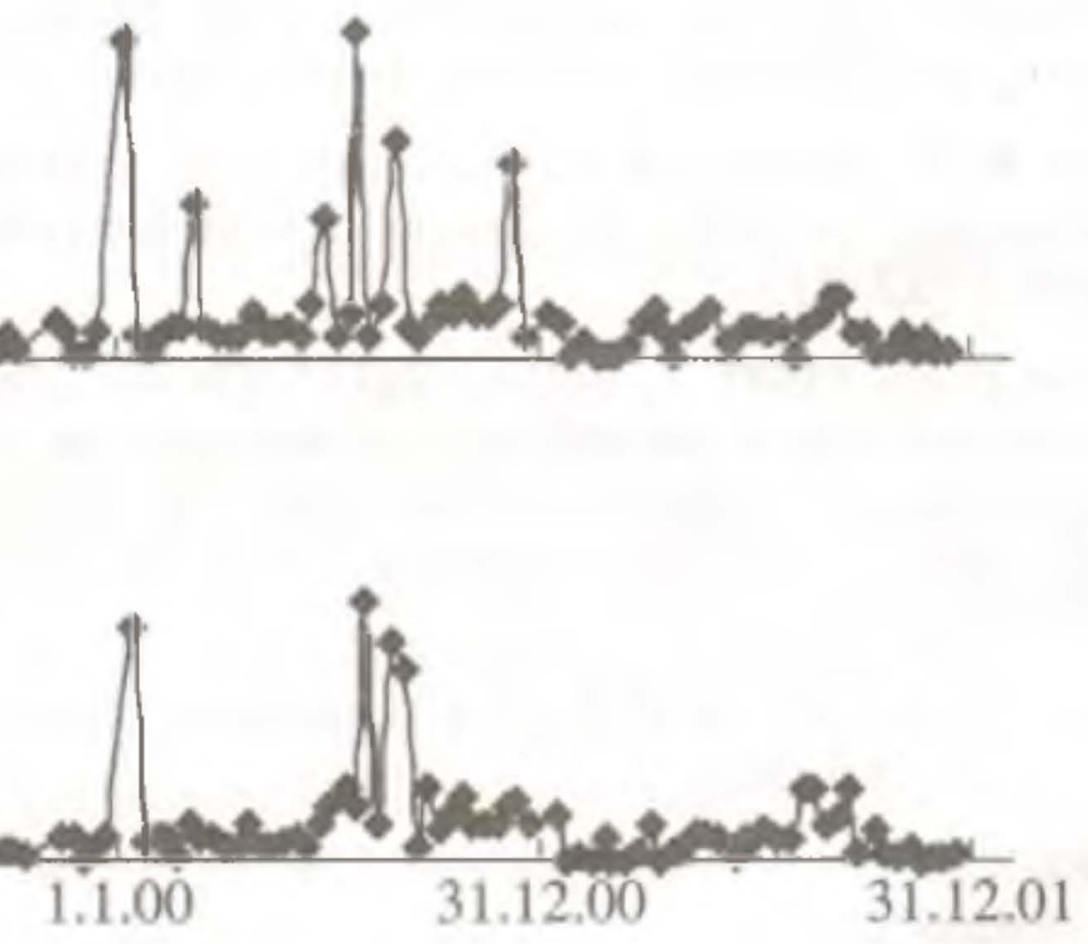

Дата отбора проб 


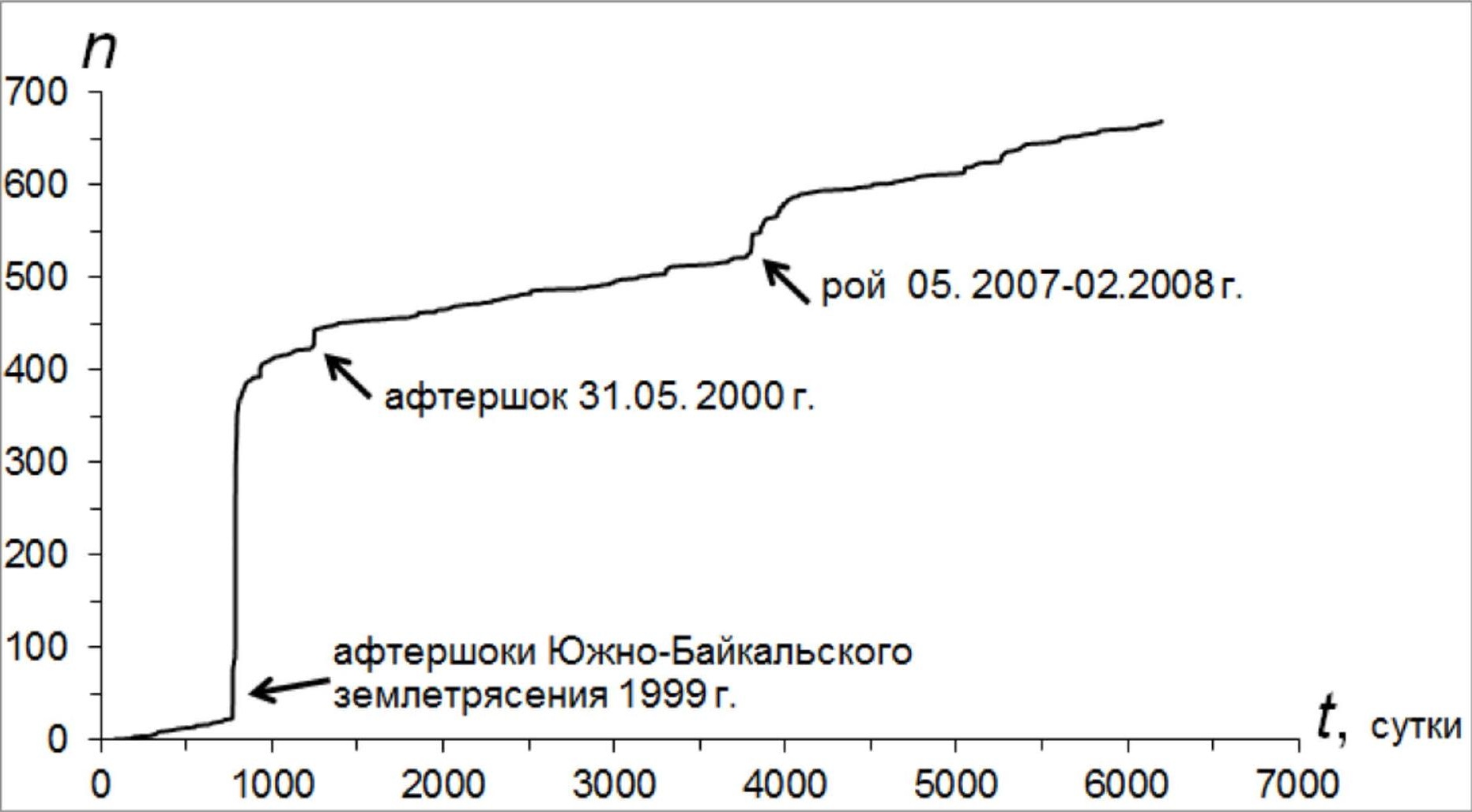




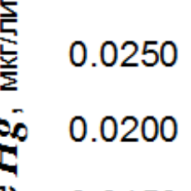

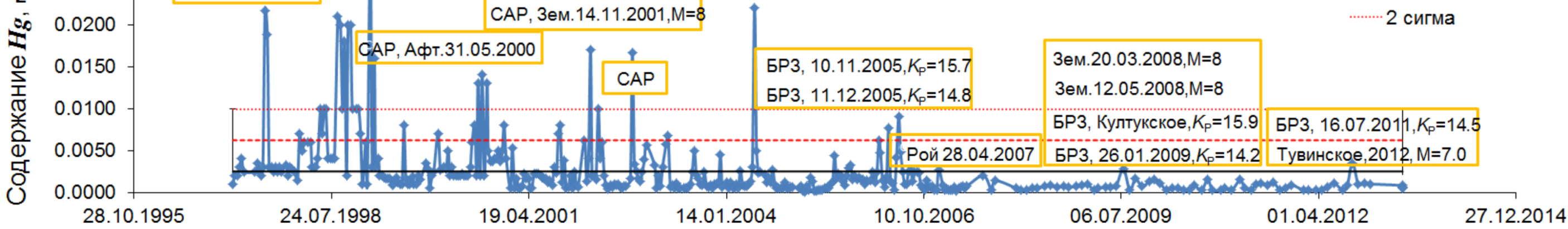

Дата: день, месяц, год 